\title{
ANTIOXIDANT ACTIVITY, TOTAL PHENOLIC CONTENT OF ESSENTIAL OILS, AND EXTRACT DETERMINED FROM NATURAL LEAVES, IN-VITRO LEAVES, AND CALLUS SOURCES OF MELALEUCA ALTERNIFOLIA - A COMPARATIVE STUDY
}

\author{
JEYAKANI M, RAJALAKSHMI M* \\ Department of Biotechnology and Bioinformatics, Bioinformatics Centre (BIF), Holy Cross College (Autonomous), Tiruchirappalli, Tamil \\ Nadu, India. Email: mdraji@gmail.com
}

Received: 08 August 2020, Revised and Accepted: 21 November 2020

ABSTRACT

Objectives: Essential oil and their compounds are getting increasing interest due to their multipurpose functional as alternatives to artificial preservatives. The aim of this study was focused to comparative analyses on hydrodistillation, total phenolic content (TPC), and antioxidant activity of essential oil derived from Melaleuca alternifolia (M. alternifolia) leaves procured from natural leaves, in-vitro leaves, and callus sources.

Methods: The essential oil was extracted using hydrodistillation. The Folin-Ciocalteu method was used to determine the TPC equivalent and antioxidant activity of essential oils.

Results: TPC of essential oil from in-vitro sources of leaves contained $14.79 \mathrm{mg}$ gallic acid equivalent/g dry plant material and its $\mathrm{IC}_{50}$ value was found to be $70 \%$ in 1-diphenyl 2-picrylhyorazyl assay. Thus, this source of essential oil showed good free radical scavenging activity.

Conclusion: The estimated biological potential was obtained in the essential oil from in-vitro sources of leaves M. alternifolia.

Keywords: Melaleuca alternifolia, Essential oil, Hydrodistillation, Total phenolic content, 1-Diphenyl 2-picrylhyorazyl.

(C) 2021 The Authors. Published by Innovare Academic Sciences Pvt Ltd. This is an open access article under the CC BY license (http://creativecommons.org/ licenses/by/4.0/) DOI: http://dx.doi.org/10.22159/ajpcr.2021v14i1.39338. Journal homepage: https://innovareacademics.in/journals/index.php/ajpcr

\section{INTRODUCTION}

Many complementary and alternative medicines have enjoyed increased popularity in recent decades. One such product is tea tree oil (TTO), the volatile essential oil derived mainly from the Australian native plant Melaleuca alternifolia. The TTO is extracted through a steam distillation process. Nowadays, TTO is very famous, and it is used in cosmetic and health care. In general, it is used for treating ringworm and athlete's foot, cuts and scrapes, acne, dandruff, and skin infections such as herpes, wounds, warts, burns, insect bites, nail mycosis, colds, sore throat, gingival infections, hemorrhoids, and vaginal infections [1-5]. Besides, it also has other therapeutic properties such as anti-inflammatory, antioxidants, anticancer $[6,7]$, antibacterial, antifungal, antiviral, and also analgesic properties [8-10]. Efforts to validate their use have seen their putative therapeutic properties come under increasing scrutiny in-vitro and, in some cases, in-vivo. Obtaining extracts from the in-vitro tissues is easier than that from complex tissues of a plant. Furthermore, the quality of the phytochemicals can be improved through in-vitro propagation of plants to produce potential medicinal compounds [11] and plant tissue culture techniques serve this opportunity in tailoring the chemical profile of the plant through manipulating the chemical or physical microenvironment. Known for its antimicrobial properties, TTO is incorporated as the active ingredient in many topical formulations widely available over the counter in Australia, Europe, and North America and is marketed as a remedy for various ailments [7] used to treat cutaneous infections. TTO from M. alternifolia is composed of various monoterpenes, sesquiterpenes, and aromatic compounds. From about 100 terpenes found in TTO, more than 60 individual substances have been identified. The monoterpenes terpinen-4ol, $\gamma$-terpinene, $\alpha$-terpinene, 1,8-cineole, p-cymene, $\alpha$-terpineol, $\alpha$-pinene, terpinolene, limonene, and sabinene account for $80-90 \%$ of the oil [12].

\section{METHODS}

\section{Plant collection}

The leaves of M. alternifolia were collected from the commercial plantations present at Idukki, Kerala, India. The species was authenticated in the Department of Botany, Holy Cross College (Autonomous), Tiruchirappalli, India and a voucher specimen are preserved in the herbarium of the department.

Preparation of plant material and extraction of essential oil The fresh leaves of M. alternifolia (from natural, in-vitro, and in-vivo plant sources) were harvested (Fig. 1) and washed with water to obliterate dirt, and then the leaves were subjected to hydrodistillation for $6 \mathrm{~h}$. The extracted essential oils were dried over anhydrous sodium sulfate to remove any trace of water and stored in sealed glass vials at $4^{\circ} \mathrm{C}$ until further analysis. The yield was calculated according to the volume of obtained essential oil and was expressed on the basis of fresh weight $(\mathrm{v} / \mathrm{w})$.

\section{Determination of total phenolic content (TPC)}

The determination of TPC was done by the method reported by Ibrahim et al. [13] with slight modifications. A mixture of sample solution $(1 \mathrm{ml})$, Folin-Ciocalteu reagent $(0.5 \mathrm{ml})$, and ultrapure water $(5 \mathrm{ml})$ was incubated at room temperature (RT) for $5 \mathrm{~min}$. Then, $1 \mathrm{ml} \mathrm{Na}_{2} \mathrm{CO}_{3}$ $(5 \% \mathrm{w} / \mathrm{v})$ solution was added and incubated for $60 \mathrm{~min}$ at RT in the dark. The absorbance of the above mixture was measured at $760 \mathrm{~nm}$ using ultraviolet (UV)-spectrophotometry. Ethanol (70\%) and gallic acid were used as negative and positive controls, respectively. The TPC of the sample was compared to a gallic acid standard curve $(\mathrm{y}=0.011 \mathrm{x}$ $\left.+0.014 ; R^{2}=0.996\right)$ and expressed relative to the equivalent standard concentrations (mg GAE/g dw, expressed as TPC per g powder). All determinations were performed in triplicates. 


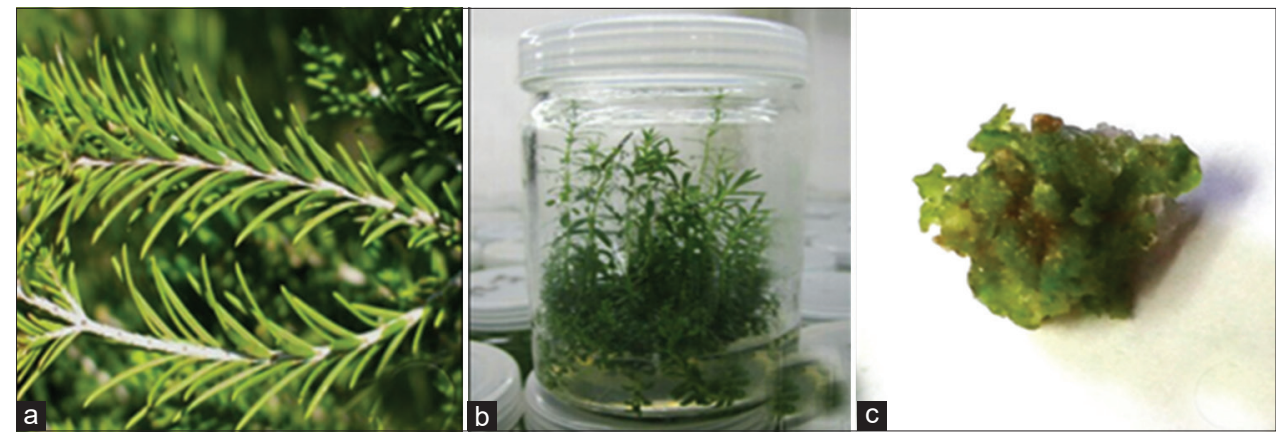

Fig. 1: Melaleuca alternifolia plant sources (a). Natural leaves (b). In-vitro leaves (c). Callus

\section{Antioxidant assays}

The antioxidant activity of the extracts was measured based on the scavenging activity of the stable 2,2-Diphenyl-1-picrylhydrazyl (DPPH) free radical assay [14] according to the method described by Williams et al. with slight modifications. One milliliter of $0.1 \mathrm{mM}$ DPPH solution in methanol was mixed with $1 \mathrm{ml}$ of essential oil solution of varying concentrations $(200,400$, and $600 \mu \mathrm{g})$. The corresponding blank sample was prepared, and L-Ascorbic acid (1-100 $\mu \mathrm{g} / \mathrm{ml})$ was used as a reference standard. Mixture of $1 \mathrm{ml}$ methanol and $1 \mathrm{ml}$ DPPH solution was used as control. The decrease in absorbance was measured at $517 \mathrm{~nm}$ after $30 \mathrm{~min}$ in the dark using a UV-spectrophotometer. The percentage of inhibition was calculated as

$$
\% \text { of inhibition }=(\mathrm{A} \text { of control }-\mathrm{A} \text { of Test }) / \mathrm{A} \text { of control } * 100
$$

\section{RESULTS}

Essential oil yield from natural leaves, in-vitro leaves, and callus sources of M. alternifolia

The yield of hydrodistillation essential oils from M. alternifolia in-vitro leaves was $50 \%(\mathrm{v} / \mathrm{w})$ (Table 1) and it was characterized by a pale yellowish color and pleasant aromatic fragrance.

\section{Estimation of TPC}

As shown in Table 2, phenolic content TPC was estimated by the FolinCiocalteu colorimetric method using gallic acid as standard the mean value of TPC. The phenolic compounds are often correlated to the antioxidant activity due to their capability to act as electron donors in free radical reaction. The TPC quantifiable from M. alternifolia in-vitro leaves was (14.79 $\mathrm{mg} \mathrm{GAE} / \mathrm{g} \mathrm{dw}$ ).

\section{DPPH assay}

The antioxidant activity of TTO was analyzed using DPPH assay and ascorbic acid was taken as standard (Table 3). While essential oils from three different sources showed approximately equal inhibitory activity, the essential oil derived from in-vitro leaves of M. alternifolia showed $70 \%$ inhibition for the concentration of $600 \mu$. The concentration of essential oils with a concomitant increase in radical scavenging was observed and the values were recorded as a percentage of inhibition.

\section{DISCUSSION}

The yield of essential oils from leaves of M. alternifolia extracted by hydrodistillation method from the natural leaves, in-vitro leaves, and callus sources in the present study was in close agreement with other studies [15], where it has been reported with a similar yield of the essential oil from M. alternifolia in-vitro leaves was $0.50 \%$. Indeed, the extraction of phenolic compounds from their natural matrix is complex by their diversity and their susceptibility to oxidation and hydrolysis. Similarly, several factors influence the amount of phenolic components such as variety, environmental conditions, and the mode of keep substrates extraction, the degree of ripening and genetic agents as well as many parameters related to the extraction methods such as temperature, time, solvent to solid ratio, and solvent type [16]. According to the present findings, the TPC of this oil was $14.79 \mathrm{mg}$
Table 1: Total yield of essential oils

\begin{tabular}{lll}
\hline S. No. & Sources of essential oils & Essential oil yield (ml/g plant) \\
\hline 1. & Natural leaves & $0.49 \pm 0.11$ \\
2. & Callus & $0.47 \pm 0.17$ \\
3. & In-vitro leaves & $0.50 \pm 0.13$ \\
\hline
\end{tabular}

Each value represents mean \pm SD done in triplicates, $p$ value $<0.05$ is considered significant

Table 2: TPC estimation

\begin{tabular}{lll}
\hline S. No. & Sources & TPC $(\mathbf{m g ~ G A E} / \mathbf{g ~ d w})$ \\
\hline 1. & Natural leaves & $14.63 \pm 1.87$ \\
2. & Callus & $14.71 \pm 1.96$ \\
3. & In-vitro leaves & $14.79 \pm 1.62$ \\
\hline
\end{tabular}

TPC: Total phenolic content, Each value represents mean \pm SD done in triplicates, $p$ value $<0.05$ is considered significant

Table 3: Antioxidant activity of essential oils

\begin{tabular}{llll}
\hline S. No. & Sources of essential oils & $\begin{array}{l}\text { Concentration } \\
(\boldsymbol{\mu l})\end{array}$ & $\begin{array}{l}\text { Percentage of } \\
\text { inhibition }\end{array}$ \\
\hline 1. & Natural leaves & 600 & $58.52 \pm 1.31$ \\
2. & Callus & 600 & $62.21 \pm 1.40$ \\
3. & In-vitro leaves & 600 & $70.41 \pm 1.02$ \\
\hline Each value represents mean \pm SD done in triplicates, p value $<0.05$ is considered \\
significant
\end{tabular}

GAE/g dw. TPC correlates with the antioxidant activity of the extract and our results were similar to those previously reported studies $[17,18]$. This essential oil is as good as a natural antioxidant exhibiting similar antioxidant activity resembling clove oil [19], due to their antioxidant activity; they are capable to scavenge the free radicals [20], which are dangerous for the body and could also possibly possess other therapeutic benefits such as anti-inflammatory, antibacterial, and anticancer activity [21-23].

\section{CONCLUSION}

Hence, they can be used in drug formulations, and more research can be carried out in the future to explore the medicinal properties of these oils.

\section{AUTHORS' CONTRIBUTION}

Ms. Jeyakani did all the experimental work and writing the article. Dr. Rajalakshmi did research guidance and critical revision of manuscript.

\section{CONFLICTS OF INTEREST}

The authors declare no conflicts of interest. 


\section{REFERENCES}

1. Satchell AC, Saurajen A, Bell C, Barnetson RS. Treatment of dandruff with 5\% tea tree oil shampoo. J Am Acad Dermatol 2002;47:852-5.

2. Hammer K, Carson C, Riley T. Antifungal activity of the components of Melaleuca alternifolia (tea tree) oil. J Appl Microbiol 2003;95:853-60.

3. Humphery EM. A new Australian germicide. Med J Aust 1930;1:417-8.

4. Penfold AR, Morrison FR. Bulletin No. 14. Part 1: Australian Tea Trees of Economic Value. $3^{\text {rd }}$ ed. Sydney, Australia: Thomas Henry Tennant, Government Printer; 1946.

5. Lahkar S, Das MK, Bora S. An overview on tea tree (Melaleuca alternifolia) oil. Int J Pharm Phytopharmacol Res 2013;3:250-3.

6. Kim HJ, Chen F, Wu C, Wang X, Chung HY, Jin Z. Evaluation of antioxidant activity of Australian tea tree (Melaleuca alternifolia) oil and its components. J Agric Food Chem 2004;52:2849-54.

7. Carson CF, Hammer KA, Riley TV. Melaleuca alternifolia (tea tree) oil: A review of antimicrobial and other medicinal properties. Clin Microbiol Rev 2006;19:50-62.

8. Brophy JJ, Davies NW, Southwell IA, Stiff IA, Williams LR. Gas chromatographic quality control for oil of Melaleuca terpinen-4-ol Type (Australian tea tree). J Agric Food Chem 1989;37:1330-5.

9. Carson CF, Ashton L, Dry L, Smith DW, Riley TV. Melaleuca alternifolia (tea tree) oil gel $(6 \%)$ for the treatment of recurrent herpes labialis. J Antimicrob Chemother 2001;48:450-1.

10. Vazquez JA, Zawawi AA. Efficacy of alcohol-based and alcohol-free Melaleuca oral solution for the treatment of fluconazole-refractory oropharyngeal candidiasis in patients with AIDS. HIV Clin Trials 2002;3:379-85.

11. Rao RS, Ravishankar G. Plant cell cultures: Chemical factories of secondary metabolites. Biotechnol Adv 2002;20:101-53.

12. Southwell IA, Hayes AJ, Markham JL, Leach DN. The search for optimally bioactive Australian tea tree oil. Acta Hort 1993;334:265-75.

13. Ibrahim MM, Al Sahli AA, Alaraidh IA, Al-Homaidan AA, Mostafa EM,
El-Gaaly GA. Assessment of antioxidant activities in roots of Miswak (Salvadora persica) plants grown at two different locations in Saudi Arabia. Saudi J Biol Sci 2015;22:168-75.

14. Williams BW, Cuvelier ME, Berset C. Use of a free radical method to evaluate antioxidant activity. LWT Food Sci Technol 1995;28:25-30.

15. Bouaziz M, Yangui T, Sayadi S, Dhouib A. Disinfectant properties of essential oils from Salvia officinalis L. cultivated in Tunisia. Food Chem Toxicol 2009;47:2755-60.

16. Kapoor LD, Singh A, Kapoor SL, Srivastava SN. Survey of Indian plants for saponins, alkaloids and flavonoids. Lloydia 1969;32:297-304.

17. Tchabo W, Ma Y, Engmann FN, Zhang H. Ultrasound-assisted enzymatic extraction (UAEE) of phytochemical compounds from mulberry (Morus nigra) must and optimization study using response surface methodology. Ind Crops Prod 2015;63:214-25.

18. Hou W, Zhang W, Chen G, Luo Y. Optimization of extraction conditions for maximal phenolic, flavonoid and antioxidant activity from Melaleuca bracteata leaves using the response surface methodology. PLoS One 2016;11:e0162139.

19. Lee KG, Shibamoto T. Antioxidant property of aroma extract isolated from clove buds [Syzygium aromaticum (L.) Merr. et Perry]. Food Chem 2001;74:443-8.

20. Chaillou HI, Nazareno M. New method to determine antioxidant activity of polyphenols. J Agric Food Chem 2006;54:8397-402.

21. Aldo G, Timpanaro R, Benedetta B, Maria FP, Giuseppe B, Castro A. In vitro antiviral activity of Melaleuca alternifolia essential oil. Lett Appl Microbiol 2009;49:806-8.

22. Terzi V, Morcia C, Faccioli P, Valè G, Tacconi G, Malnati M. In vitro antifungal activity of the tea tree (Melaleuca alternifolia) essential oil and its major components against plant pathogens. Lett Appl Microbiol 2007; 44:613-8

23. Lan YW, Wen CH, Tian AS, Rong D, Yanping L. Chemical composition, antioxidant and bioactivities of essential oils from Melaleuca bracteata leaves. Plant Prot Sci 2020;56:18-29. 